\title{
PETER KONWITSCHNY A JEHO OPERNO-DIVADELNÁ KRITIKA KAPITALISTICKEJ MORÁLKY
}

\author{
MICHAELA MOJŽIŠOVÁ
}

Ústav divadelnej a filmovej vedy Centra vied o umení Slovenskej akadémie vied, Bratislava

\begin{abstract}
Abstrakt: Divadelná tvorba nemeckého operného režiséra Petra Konwitschného je principiálne determinovaná jeho l’avicovým politickým presvedčením. Štúdia sa koncentruje na niektoré z fenoménov západnej (kapitalistickej) spoločnosti, ktoré režisér vo svojich inscenáciách kontinuálne podrobuje kritike. Popri odmietaní patriarchálnych princípov organizácie spoločnosti je to predovšetkým závislost modernej civilizácie od materiálnych komodít, jej konzumný spôsob života a z neho vyplývajúci rozvrat morálnych hodnôt.
\end{abstract}

Kl'účové slová: Peter Konwitschny, opera, lavicovo angažované divadlo, kritika kapitalizmu

Uhol pohladu, z ktorého nemecký režisér Peter Konwitschny interpretuje operné predlohy, je determinovaný jeho l’avicovou ideologickou orientáciou a principiálnym odmietaním kapitalizmu. Pritom však, ako v úvodnej štúdii k monografii o režisérovi zdôrazňuje jej zostavovatel'ka Andrea Welker, pozitívny vztah k marxizmu bol u Konwitschného vždy otázkou filozofie, nie straníckej príslušnosti: „V Nemeckej demokratickej republike sa z marxizmu stalo náboženstvo, ale on [Peter Konwitschny - pozn. M. M.] ho stále považoval za dôležitú vedu. Pre neho, vychovaného v dialektickom materializme, kolaps Východu v žiadnom prípade neznamenal, že by komunizmus nepredstavoval alternatívu ku kapitalizmu. Pretože komunizmus v praxi nikdy neexistoval, aspoň doteraz nie. A ako filozofia podl'a Petra Konwitschného neskrachoval. " ${ }^{1}$ Režisér bol v polovici sedemdesiatych rokov konfrontovaný s ponukou vstúpit’ do štátotvornej Jednotnej socialistickej strany Nemecka (Sozialistische Einheitspartei Deutschlands - SED). Dostal ju prostredníctvom svojej tútorky, režisérky Ruth Berghaus, ktorej robil asistenta v Berliner Ensemble, no neprijal ju: „Neželal si žiadne osobné spojenia so stranou. Cítil sa byt’ skrz naskrz politickým človekom², ale nie straníkom. Jeho sympatie patrili socializmu v zmysle Bertolta Brechta, nie v zmysle SED. ${ }^{\text {“3 }}$ Ruth Berghaus jeho rozhodnutie rešpektovala a - ako podotýka Andrea Welker - „neraz ho pred stranou kryla“. ${ }^{4}$

Svoj spoločensko-kritický svetonázor, vychádzajúci z ideálov komunizmu, Peter Konwitschny formuloval a formuluje nielen na divadelných javiskách, ale aj v mnohých interview publikovaných $\mathrm{v}$ tlači či $\mathrm{v}$ bulletinoch $\mathrm{k}$ inscenáciám. Napríklad

\footnotetext{
${ }^{1}$ WELKER, A. (ed.). Peter Konwitschny. „Mensch, Mensch, Mensch!“ Oper als Zentrum der Gegenwart. Weitra : Verlag Bibliothek der Provinz, 2015, s. 15.

${ }^{2}$ Termín „der politische Mensch“ je u Konwitschného dôležitou kategóriou. Podobne ako Heiner Müller, aj on verí v to, že každý človek - teda aj umelec - je politický. To znamená, že každá umelecká výpoved’ a teda aj réžia je politická, no nie v zmysle straníckej či dennej politiky, ale v zmysle morálky.

${ }^{3}$ WELKER, A. Peter Konwitschny. "Mensch, Mensch, Mensch!“ Oper als Zentrum der Gegenwart, s. 19.

${ }^{4}$ Tamže.
} 
v rozhovore pre nemecký dvojmesačník Oper \& Tanz (2001) sa vyjadril: „Súhlasím s Marxovou teóriou, že celý tunajší chaos je spôsobený súkromným vlastníctvom výrobných prostriedkov. Z pohl'adu Ericha Fromma to znamená ,mat' alebo byt‘. (...) Koncentrácia majetku a kapitálu v rukách pár l’udí je vel’mi silná. (...) Axiómy našej civilizácie sú nesprávne. Základné predpoklady o organizácii živej matérie sú chybné. “5 Rovnakú tézu rozvinul v rozhovore poskytnutom pri príležitosti bratislavského remaku inscenácie Pucciniho Madame Butterfly (Slovenské národné divadlo, 2007), ktorú vyložil ako tragédiu neporozumenia medzi mužom a ženou, generovanú všadeprítomnou sociálnou nespravodlivost’ou: „Naša patriarchálna kultúra je založená na nesprávnych axiómach. Vlastníctvo výrobných prostriedkov sa premietne aj do vzt’ahov. " ${ }^{16} \mathrm{Na}$ komentár redaktorky, že takéto názory sa označujú za radikálne lavicové či feministické, reagoval pozitívne: „To sedí. Filozoficky som marxista. Nikdy sa nezmierim s kapitalizmom, lebo je nel’udský a nivočí zem. (...) V časoch úpadku sú nebezpečenstvá číhajúce na lásku vel'ké. Len ak sa vlastnenie, to neštastné slovko mat', priblíži k nule, len potom narastie priestor pre lásku. Najväčším nepriatelom života je sýtost'. “7 Jeho odpoved’ na otázku, čo by oslobodilo svet, znela: "Zrušenie peňazí a kapitalizmu. “8

Zrejme najvýraznejším a v inscenáciách najsugestívnejšími výrazovými prostriedkami reflektovaným bodom l’avicového svetonázoru Petra Konwitschného je kritický pohl'ad na patriarchálne usporiadanie západnej spoločnosti a poukazovanie na nespravodlivost’ postavenia ženy v mužskom svete. No ked’že tejto, režisérom viacnásobne spracovanej téme sa venujeme v inej práci ${ }^{9}, \mathrm{v}$ predkladanej štúdii upriamime pozornost' na d’alšie spoločenské fenomény, ktoré Konwitschny kontinuálne podrobuje kritike: na závislost' modernej civilizácie od materiálnych komodít, na konzumný spôsob jej života a z neho vyplývajúci rozvrat morálnych hodnôt. Napokon, aj citovanú inscenáciu Madama Butterfly - hoci sa viac než na konflikt západnej (americkej) a východnej (japonskej) kultúry koncentrovala na bezútešnú situáciu opustených žien a komplikovaný osud detí vyrastajúcich v takomto prostredí - otváral obraz pranierujúci kapitalistickú bezohl'adnost'. Stretnutie Pinkertona s dohadzovačom Gorom, v ktorom sa rieši 99-ročný „prenájom“ japonskej nevesty pre amerického dôstojníka, sa odohrávalo na proscéniu, zatial' čo sa na zatiahnutú oponu premietali čiernobiele fotografie mladučkých dievčat, každá opatrená cenovkou: Všetko a všetci sú na predaj, po zlave len za pár dolárov.

\section{Kritika kapitálu}

Deštruktívnu moc peňazí režisér priamočiaro odhalil v inscenácii Bergovho Wozzecka (Staatsoper Hamburg, 1998). Sociálno-kritické dielo o chudobnom vojakovi,

${ }^{5}$ KONWITSCHNY, P. - SPAHN, C. Die machen sich überhaupt keinen Kopf [Interview]. In Die Zeit, 2001 , roč. 55 , č. 19, s. $49-50$.

${ }^{6}$ KONWITSCHNY, P. - ULIČIANSKA, Z. Opery nám ukazujú, ako so sebou nezaobchádzat' [Interview]. In Sme, 2004, roč. 15, č. 280, s. 23, 6. 12. 2007.

${ }^{7}$ Tamže.

${ }^{8}$ Tamže.

${ }^{9}$ Pozri MOJŽIŠOVÁ, M. The Picture of a Family Crisis and the Criticism of Patriarchy in the Works of Director Peter Konwitschny. In KNOPOVÁ, E. (ed.). Theatre as a Value-based Discourse : Slovak Theatre and Contemporary European Theatre Culture. Bratislava : Veda, 2018, s. 152 - 166. 


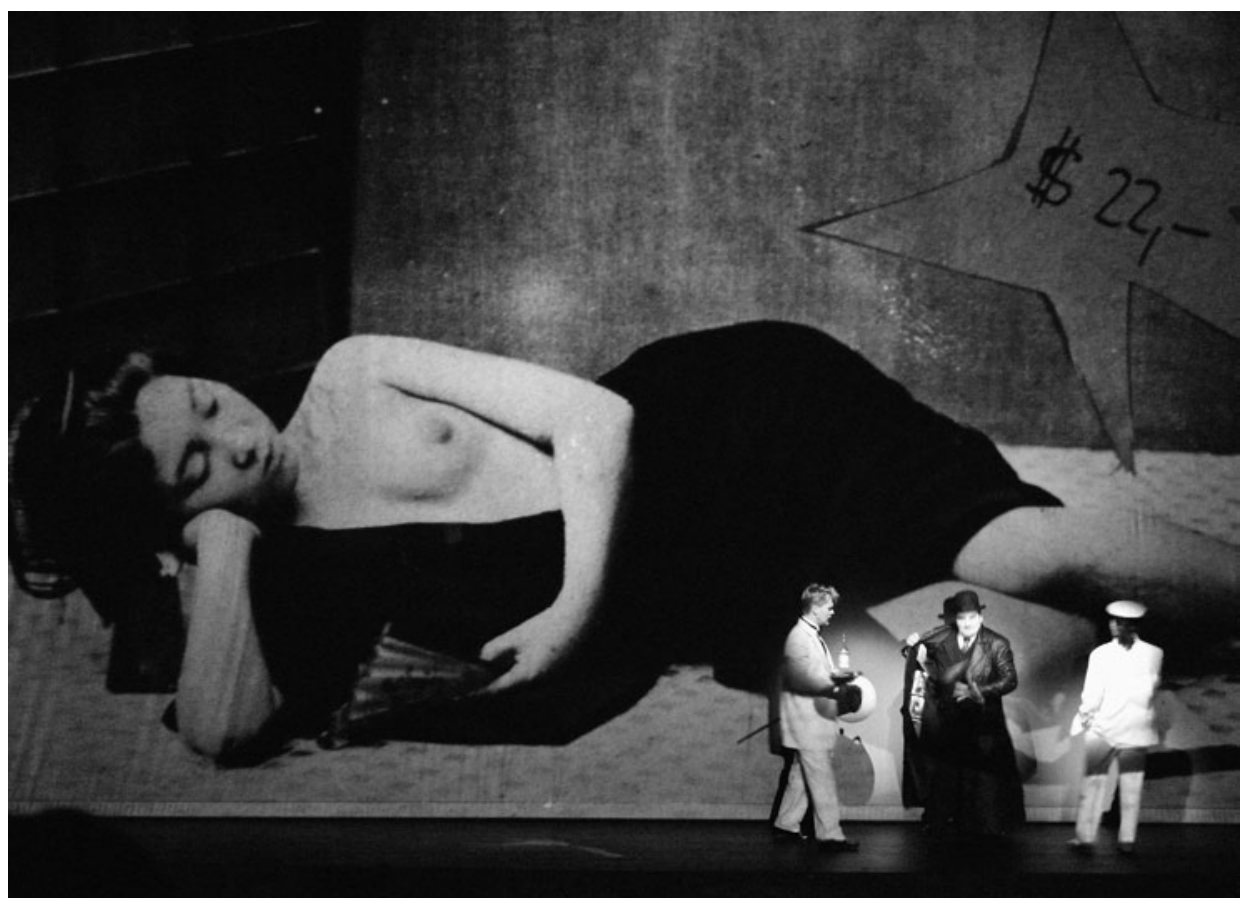

Giacomo Puccini: Madama Butterfly. Opera Slovenského národného divadla, premiéra 5. 10. 2007. Réžia Peter Konwitschny. Pavol Remenár (Sharples), Ivan Ožvát (Goro), Ludovít Ludha (Pinkerton). Foto archív SND. Snímka Alena Klenková.

ktorý nemá dostatok prostriedkov na to, aby sa oženil s matkou svojho synčeka Marie a prebral zodpovednost' za rodinu, takže v snahe zlepšit’ svoju finančnú situáciu znáša ponižovanie od dôstojníkov aj neludské pseudomedicínske pokusy Doktora, sa končí tragicky. Wozzeck v zúfalstve zavraždí Marie, pretože mu bola neverná s Tambourmajorom, a sám si vezme život. Interpretačná tradícia Bergovej opery sa od vzniku diela odvíjala zväčša v expresívnej, neraz až hyperrealistickej javiskovej poetike. Peter Konwitschny do nej radikálne zasiahol, ked’ dal opusu asketický scénografický tvar. Na prázdnej scéne pripomínajúcej bielu škatulu vystupovali muži vo frakoch a ženy v dlhých, hladkých čiernych šatách. Absencia rekvizít a kulís nadobudla funkciu principiálnej výpovede - výprava k inscenácii o materiálnej biede nemohla stát viac, než by Wozzeck zarobil za celý život: „(...) bolo to moje znechutenie, ktoré cítim, ked’ si dnes štedro zaplatený spevák nachvílu natiahne masku, nechá na natriet’ trochou sivej farby a potom nám chce hrat’ o tom, ako žijú najchudobnejší z chudobných. Také umenie je asociálne a skutočne nechutné."10

Sociálny status protagonistov polokoncertného divadelného tvaru sa nediferencoval podla žiadnych vonkajších znakov, Wozzeck bol oblečený rovnako ako

${ }^{10}$ KONWITSCHNY, P. - DEMATTIA, O. Ich möchte eine therapeutische Wirkung [Interview]. In Der Standard, 14. 11. 2003. [online]. [cit. 29. 1. 2020]. Dostupné na internete: https://www.derstandard.at/story/1476773/ich-moechte-eine-therapeutische-wirkung. 


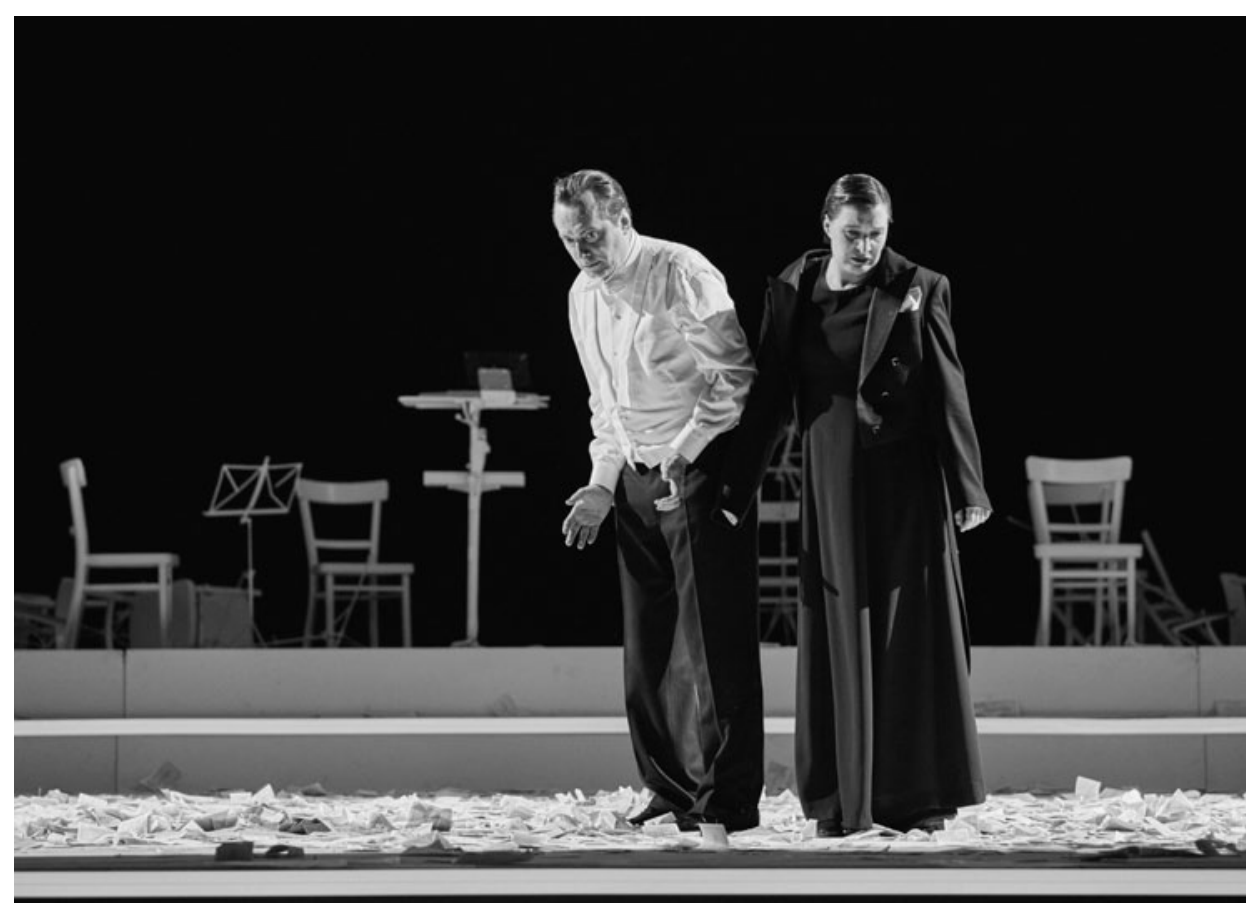

Alban Berg: Wozzeck. Staatsoper Hamburg, premiéra 27. 9. 1998, premiéra obnoveného naštudovania 14. 9. 2016. Réžia Peter Konwitschny. Georg Nigl (Wozzeck), Gut-Brit Barkmin (Marie). Foto Brinkhoff/ Mögenburg.

Hauptmann, Tambourmajor či Doktor. Všetci spolu tvorili uniformovanú masu, ktorú spájal a zároveň rozdel’oval vzt̉ah k bankovkám, ostinátne zasýpajúcim prázdne javisko. Podla režisérovho vyjadrenia publikovaného $\mathrm{v}$ bulletine sú l'udia $\mathrm{v}$ tomto diele „všetci chorí, všetci šialení, skrze peniaze vzájomne odcudzení - bez ohl'adu na to, či ich majú alebo nie“". ${ }^{11}$ Väčšina z postáv po nich túžila: Wozzeckov kamarát Andres si ich nenásytne pchal pod sako, Marie sa s nimi láskala, zboristi oblečení vo frakoch a večerných toaletách sa na svet pozerali cez bankovky s vystrihnutými dierami na oči a, brodiac sa po kolená v peniazoch, spievali o svojej chudobe. „Sýtost' nás robí chudobnými“"12 zargumentoval režisér tento vizuálny oxymoron. Podla neho „peniaze ako riadiaci princíp a náboženstvo sú príčinou nášho ohrozenia, pretože nás odcudzujú od toho, čo je skutočné ${ }^{\prime \prime 13}$.

V hamburskej inscenácii sa k nim len Wozzeck staval odmietavo, a to s až demonštratívnou intenzitou - bál sa ich, hnusili sa mu, jednu z bankoviek hystericky roz-

${ }^{11}$ KONWITSCHNY, P. - HINTZE, W. Selbst das Geld geht in Verwesung über Wozzeck von Alban Berg [Interview]. In Alban Berg: Wozzeck [Bulletin k inscenácii]. Cit. podl'a WELKER, A. (ed.). Peter Konwitschny. "Mensch, Mensch, Mensch!" Oper als Zentrum der Gegenwart, s. 309.

${ }^{12}$ KONWITSCHNY, P. - BARTZ, B. Die Reeperbahn spielt mit [Interview]. In Alban Berg: Lulu [Bulletin k inscenácii]. Cit. podla WELKER, A. (ed.). Peter Konwitschny. „Mensch, Mensch, Mensch!“ Oper als Zentrum der Gegenwart, s. 358.

${ }^{13}$ Tamže. 
trhal na kúsky. Jeho postoj mal opodstatnenie, ked’že peniaze boli nástrojom na jeho ponižovanie. Sadistický Doktor mu v rámci pokusov neprikazoval jest’ fazul'u, ako sa o tom píše v librete, ale mu popod pazuchy, medzi kolená i do úst strkal bankovky. Aj Marie bola Tambourmajorom fyzicky zneužitá a ponížená rovnakým spôsobom ako Wozzeck pri Doktorových pokusoch: na konci obrazu, ktorý sa začínal ich tancom v bare, ju jej zvodca „vypchal“ bankovkami. Napokon sa práve ony stali hrobom oboch hlavných protagonistov príbehu: Marie skončila pochovaná pod hŕbou peňazí, Wozzeck sa v nich utopil. V poslednom výjave Bergovej opery, ked' deti oznamujú Mariinmu synčekovi, ktorý sa hojdá na drevenom koníkovi, že jeho mama je mŕtva, ponechal režisér javisko prázdne. Tragický epilóg znel z reproduktorov, zatial' čo sa očiam divákov apelatívne ponúkal iba pohlad na podlahu pokrytú kobercom bankoviek.

Rovnaká rekvizita zohrala úlohu i v omnoho mladšej Konwitschného práci, v inscenácii opery Wernera Egka Peer Gynt (Theater an der Wien, 2018). Podobne ako v známej dramatickej predlohe Henrika Ibsena, aj v rovnomennej Egkovej opere opúšta mládenec Peer Gynt svoj domov, aby vo svete získal slávu a rešpekt, ktorých sa mu v rodnej dedine nedostáva. Strasti, ktoré zažíva na cestách, sú z vel'kej miery trestom za jeho sebectvo, pýchu i nezodpovednost’ vo vzt'ahoch. Ale zároveň majú katarzný potenciál - stávajú sa prostriedkom na spoznanie pravých hodnôt a dopracovanie sa $\mathrm{k}$ duševnému pokoju.

Presvedčený l'avičiar Konwitschny si v Egkovej opere pol’ahky našiel objekt na karikovanie: stali sa ním kapitalisti a l’udia ovládaní mamonom. Ríšu trollov inscenoval ako vel'ký obchodný dom, ktorý vlastní Starý ${ }^{14}$, a jej obyvatel'ov obliekol do súčasných pestrofarebných šiat prezrádzajúcich absenciu zmyslu pre vkus. Bezhlavý konzum demonštrovali kriklavé bilboardy s nápismi SALE, EXTRA BILLIG, 50\% OFF (a pod.) a nadrozmerná pätstoeurová bankovka. Aby sa Peer mohol oženit s dcérou krála trollov a prevziat po ňom trón, musí v opere absolvovat tzv. očnú skúšku: ocenit divadelné predstavenie, ktoré mu trollovia zahrajú. U Konwitschného v tejto skúške zlyhal, pretože nedokázal pochopit’ ich fascináciu dianím na televíznej obrazovke. Egkovu „Augenprobe“ interpretoval režisér v zmysle kultúrnej kritiky. Dôvodom, prečo chceli trollovia vypichnút Gyntovi oči, bol jeho odmietavý postoj k tomu, čo oni považovali za krásne. Tento obraz by sme mohli interpretovat' aj v zmysle autobiografickej projekcie režiséra, ktorého divadelné interpretácie neraz narazili na konzervatívny vkus masového publika - priatelov „mŕtvej opery“, ako neúnavne nazýva tento typ divadelných konzumentov.

V piatom obraze opery sa Peer dostáva do južnej Ameriky, kde sa prostredníctvom úplatkov a podvodov dopracuje k obrovskému majetku. V tejto časti inscenácie dosiahlo karikovanie kapitalistickej spoločnosti vrchol a výtvarný gýč bol ironicky hyperbolizovaný ad absurdum. Na zadnom prospekte sa čnel obrovský kreslený parník nesúci meno svojho majitel’a Peera Gynta, ktorý si v spoločnosti servilných finančníkov hovel pod dvojrozmernou kulisou palmy a hostil prezidenta oblečeného v nevkusnej diktátorskej uniforme. O komfort „,smotánky“ sa starali mladé černošky s banánmi na bedrových sukničkách ${ }^{15}$ (jeden z nich si Peer s chutou odtrhol) a čierni lokaji strážiaci diskrétnost’ rozhovoru ich šéfa s vplyvným podnikatelom. V tomto

\footnotetext{
${ }^{14}$ Originálny názov postavy je „Der Alte, König der Trolle“.

${ }^{15}$ Citát ikonického banana dance Josephine Baker z dvadsiatych rokov minulého storočia.
} 
obraze, kde sa napíňa miera Peerových hriechov, režisér spoločne so skladatel’om exemplárne potrestal Peera za podlahnutie mamonu. Kým sa on zabával s atraktívnou servírkou, na zadnom prospekte sa premietali čoraz menšie kreslené obrázky vzd’al'ujúceho sa parníka, ktorý mu ukradli finančníci. Nie však nadlho: najmenší obrázok zlikvidoval výbuch. Bez moci a peňazí stratil Gynt cenu a prezident ho prepustil. V tejto chvíli sa v Egkovej partitúre začína Peerova cesta za vykúpením. Kým dosiahne odpustenie v náručí verne čakajúcej Solveig, vytrpí si mnoho poníženia a strachu. V siedmom obraze opery, v ktorom sa dej vracia do ríše trollov, sa Konwitschného pestrofarebný obchodný dom zmenil na čiernobielu nočnú moru. Neznámy hlas znejúci z vel'kého bieleho mercedesu volal Peera do ríše smrti, smútočný sprievod niesol zástavy s obrazmi bankoviek.

Opät nešlo o prvé použitie tohto symbolu v režisérovej bohatej umeleckej činnosti, podobu bankovky mala aj vlajka v meste, kde žil hlavný hrdina inscenácie Čajkovského opery Piková dáma, Hermann (Oper Graz, 2011). Režisér v bulletine konštatoval, že „chamtivost’ a stavovská nadutost' ovládali staré Rusko rovnako ako dnešný svet" ${ }^{\prime 16}$. Ako často vo svojich inscenáciách, aj tu dal sociálnej kritike formu persifláže, ked' sólistov i zbor v scéne maškarného plesu obliekol do kostýmov zajačikov s obrovskými ušami, chvostíkmi a kožušinovými goliermi a nechal ich tancovat’ $\mathrm{v}$ „zvieracej“ choreografii, zatial čo sa nad nimi kýval symbol ich túžob - obrovská červená mrkva. Zdanlivú idylu baviacej sa smotánky rozbil hlavný hrdina opery Hermann, ked' tanec nečakane prerušil vloženým činoherným textom, ktorý zúrivo interpretoval v nemčine, teda rodnom jazyku väčšiny divákov, do rozsvieteného hl'adiska (rozumej, operným snobom v publiku): „Vy ste sa už museli načisto zbláznit’ s vašimi sračkami, že tu robíte takúto sprostú hudbu! Cnostná pastierka, tú tam musel Čajkovskij dokomponovat', lebo ho k tomu petrohradský inštitút donútil! Aby zasratí petrohradskí operáci vôbec pohli svoje zadky do opery. Viete vy vôbec, čo je to divadlo?!“

Ostré karikovanie konzumu charakterizuje aj Konwitschného inscenáciu opusu Paula Dessaua Lanzelot. Piata zo siedmich autorových opier tento motív priamo ponúka. Skladatel' ju skomponoval na libreto nemeckého dramatika Heinera Müllera, ktorý ho napísal podla politicko-kritickej rozprávkovej komédie ruského dramatika Jevgenija Švarca Drak, vytvorenej počas leningradskej blokády. Dessauov Lanzelot je výpoved’ou mentálne rozdvojeného umelca žijúceho v Nemeckej demokratickej republike: navonok ho prezentovali ako uctievaného skladatel'a a zahŕňali poctami, no pritom sa vedelo o jeho nesúhlase s politickým vedením NDR, devalvujúcim myšlienky socializmu, ktorého ideám Dessau principiálne veril.

Archetypálny príbeh rytiera, ktorý zabije draka, zachráni princeznú a vyslobodí král'ovstvo, prepísali Dessau s Müllerom ostrým satirickým perom. Obyvatelia ich mestečka netúžia po slobode a panny obetujú Drakovi dobrovolne, ako odmenu za to, že kedysi pradávno zničil choleru, ked’ horúcim dychom prevaril kontaminovanú vodu v jazere. Na život v diktátorskom režime si zvykli, nechali sa skorumpovat materiálnymi benefitmi a o zmenu systému nemajú záujem. No Lanzelot aj tak vyzve Draka na súboj, pretože chce zachránit’ milovanú Elsu, dcéru miestneho archivára. Draka zabije, ale ked' vyčerpaný bojom nepríde včas na svoju svadbu s Elsou, po-

\footnotetext{
${ }^{16}$ KONWITSCHNY, P. - BARTZ, B. Was unter der Oberfläche brodelt [Interview]. In Piotr Iljič Čajkovskij: Pique Dame [Bulletin k inscenácii]. Graz : Open Graz, 2011, s. 4.
} 


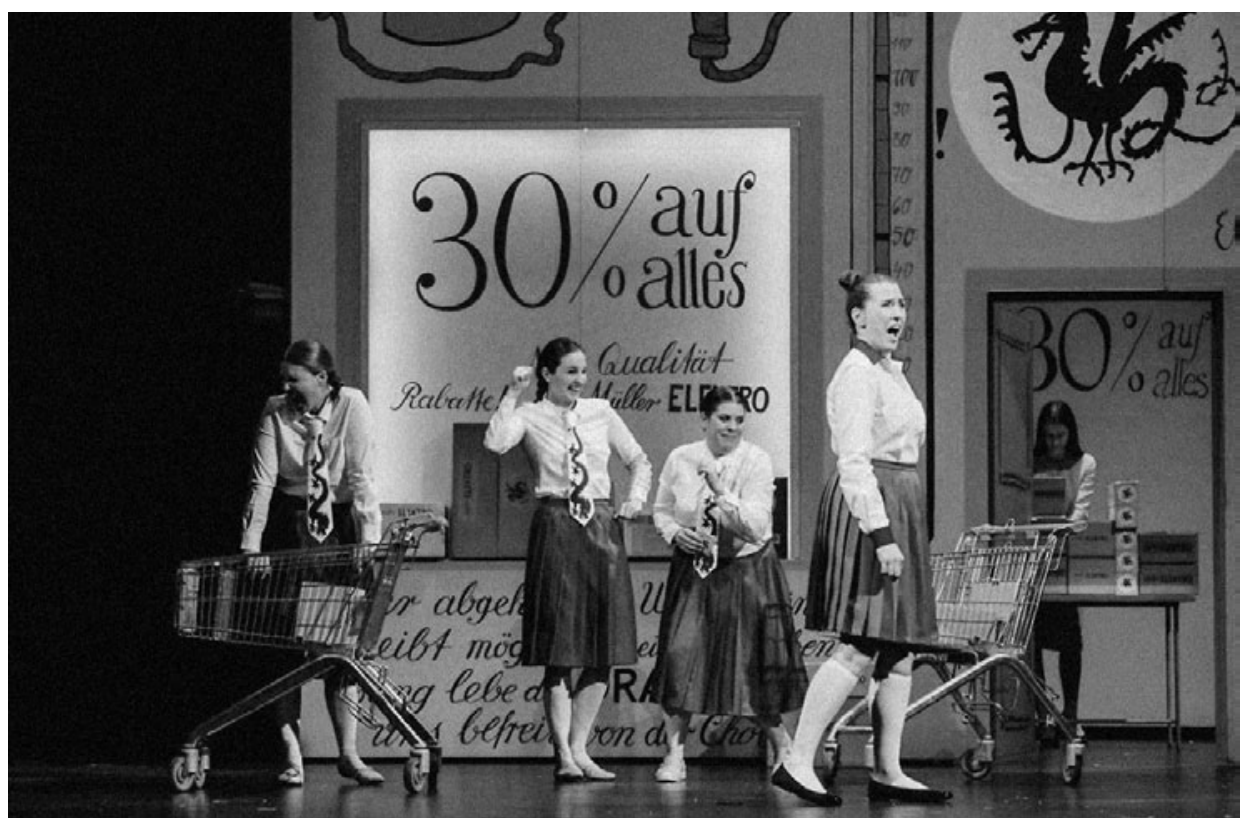

Paul Dessau: Lanzelot. Deutsches Nationaltheater Weimar, premiéra 23. 11. 2019. Réžia Peter Konwitschny. Foto archív DNT Weimar. Snímka Candy Welz.

važujú ho za mŕtveho. To využije Starosta, ktorý dovtedy s režimom kolaboroval, vyhlási sa za vítaza nad Drakom a uzurpuje si moc. Ludia opät prijímajú nadiktované pravidlá hry, ktoré im zabezpečujú síce duchovne neslobodný, ale materiálne pohodlný život. V tej chvíli prichádza Lanzelot, oslobodzuje politických väzňov a mestečku ponúka život bez totality. Záverečný spev „To ostatné je radost' - radost’ je to ostatné" však vyznieva vel'mi rozpačito, v dôsledku čoho ostáva na konci opery visiet’ vo vzduchu otázka: Dokážu l’udia slobodu vôbec prijat??

Po svetovej premiére v Staatsoper Berlin (1969) a d’alších dvoch bezprostredne nasledujúcich naštudovaniach sa interpretačná tradícia Dessauovej opery nadlho prerušila. Až v sezóne 2019/2020 ju v koprodukcii uviedli dve menšie nemecké scény vo Weimare a Erfurte. Polstoročné embargo mohla spôsobit jednak enormná interpretačná náročnost’ opusu, sčasti aj inam nasmerovaná dramaturgická orientácia východonemeckého operného divadla ${ }^{17}$, ale tiež bipolárna politická ",nepohodlnost" diela, ako ju zhrnul nemecký operný kritik Roland H. Dippel: „Drak, ktorý určuje dej zabíjaním a jeho metodikou, môže byṫ diktátorom ako Stalin, alebo akumuláciou bezciel'nej sily a rozpútaného turbo-kapitalizmu. Müller a Dessau nechali túto vec otvorenú. “18 Podobný názor vyslovil aj režisér, ked’ na otázku, prečo mal opus podl’a neho také krátke inscenačné dejiny, odpovedal: „Nie že by toto dielo bolo nezaují-

\footnotetext{
${ }^{17}$ Operné divadlá v NDR sa v poslednej tretine 20. storočia zameriavali predovšetkým na reinterpretáciu tradičných repertoárových titulov v duchu emocionálne verného psychologického realizmu.

${ }^{18}$ DIPPEL, R. H. Im Kampf gegen die totalitäre Macht. In Oper \& Tanz, 1/2020. [online]. [cit. 12. 3. 2020]. Dostupné na internete: https://www.operundtanz.de/archiv/2020/01/berichte_02_lanzelot.shtml ISSN 0474-2478.
} 


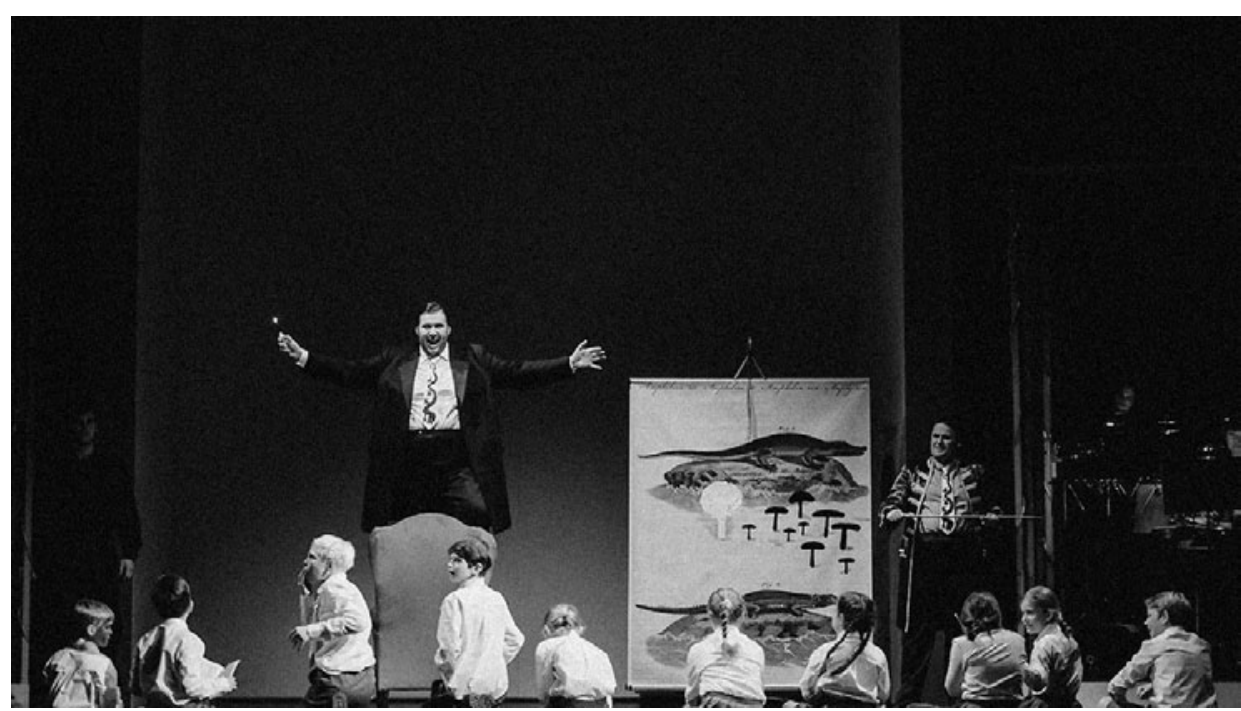

Paul Dessau: Lanzelot. Deutsches Nationaltheater Weimar, premiéra 23. 11. 2019. Réžia Peter Konwitschny. Oleksandr Pushniak (Drak), Uwe Stickert (Heinrich). Foto archív DNT Weimar. Snímka Candy Welz.

mavé, ono bolo jednoducho až príliš zaujímavé, a preto skoro zmizlo. S politickými kusmi to tak chodí. " ${ }^{19}$

S názorom kritiky, že „Peter Konwitschny je azda jedinou správnou vol'bou pre réžiu tohto zabudnutého diela“ ${ }^{“ 20}$, sa nedá iné než súhlasit. Nielen preto, že ako občana bývalej NDR ho s Dessauom spája ambivalentný osud intelektuála žijúceho a tvoriaceho v zriadení, ktoré v praxi deformovalo a devalvovalo ideály, ktorým veril. Ale tiež z toho dôvodu, že v Dessauovej opere sa priam esenciálne pretavuje svetonázor Konwitschného, ktorý vo svojej divadelnej tvorbe vytrvalo pranieruje otupenú, konzumom zmanipulovanú spoločnost'. Mestečko v jeho režijnej koncepcii odmietalo vnímat' nebezpečenstvo totality aj preto, že Drak nebol obludou s odpudivými šupinami. Tvorcovia mu dali výzor charizmatického manipulátora v dobre padnúcom fraku. Pri stretnutiach s občanmi rozdával strojené úsmevy, v škole osobne vymýval ich detom mozgy prednáškami z dračích dejín, v ktorých zohrával ultimatívnu rolu („Na počiatku som bol ja“) a dbal na to, aby l'ud’om zahlteným hmotnými statkami neostávala kapacita na intelektuálne náročnejšiu činnost'. V obchode nabitom tovarom občania chamtivo plnili nákupné vozíky a v miestnej krčme sa opíjali Drachenblutom (Dračou krvou), ktoré reklamný slogan vyzdvihoval ako najlepšie pivo všetkých čias. V scénickom riešení Helmuta Bradeho sa dali odčítat spoločné motívy s Peerom Gyntom: obchodný dom lákal zákazníkov plagátmi ohlasujúcimi výpredaje, zariadenie ich príbytkov svedčilo o malomeštiackom nevkuse. Jedinými obyvatel'mi, ktorí sa Drakovi vzpierali, boli popri Lanzelotovi a jeho milej Else miestne mačky vedené Elsiným kocúrom a pár príslušníkov podzemného odboja. Naproti tomu, Elsin

${ }^{19}$ KONWITSCHNY, P. - BARTZ, B. - WEGNER, H.-G. Lanzelot in Weimar [Interview]. In Paul Dessau: Lanzelot [Bulletin k inscenácii], s. 9.

${ }^{20}$ BAYER, R. Ako (ne)zabit’ draka. In Hudobný život, 2020, roč. 52, č. 1 - 2, s. 43. 


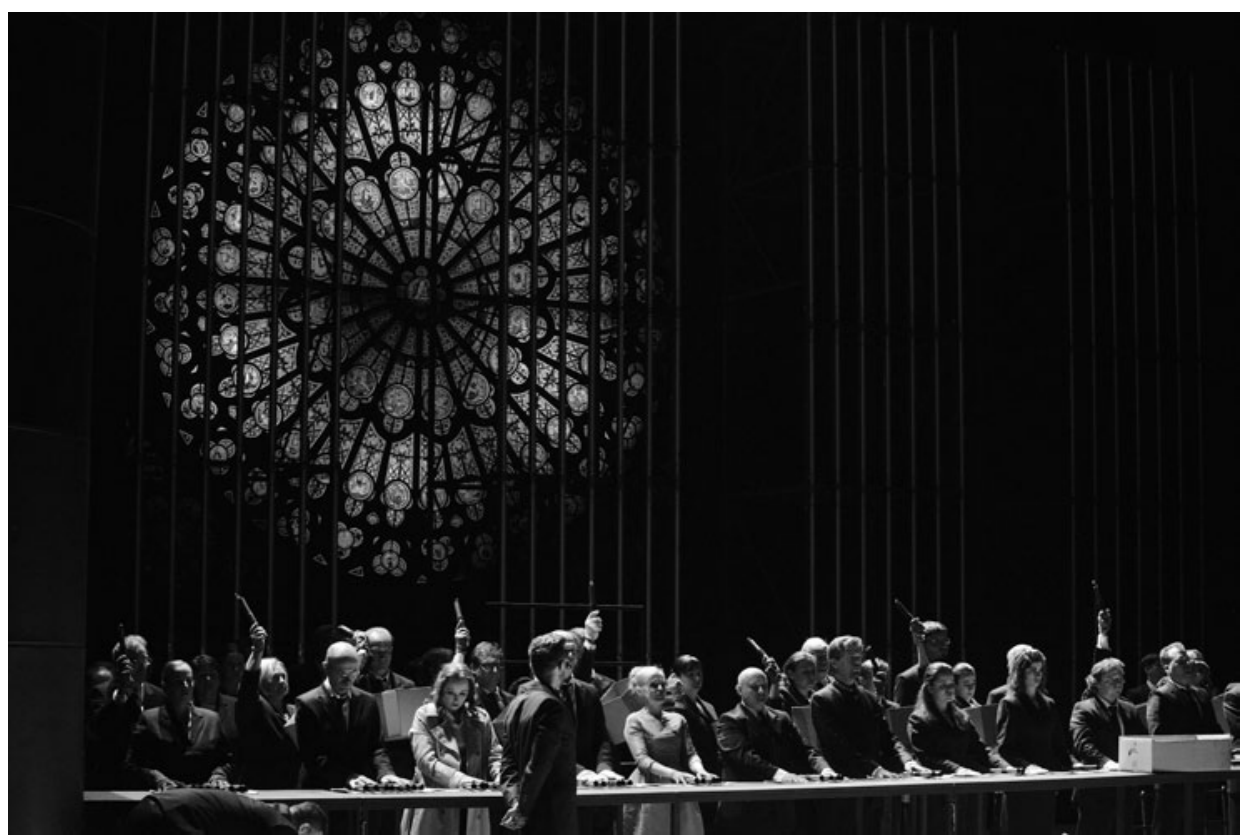

Jacques Fromental Halévy: Židovka. Opera Slovenského národného divadla, premiéra 7. 4. 2017. Réžia Peter Konwitschny. Foto archív SND. Snímka Pavol Breier.

otec sa submisívne podriadil Drakovej vôli a jej pôvodný snúbenec ju bez zaváhania vymenil za post Drakovho kancelára.

\section{Pacifizmus a ekokritika}

Drak v Konwitschného inscenácii Lanzelota mal obyvatel'ov mesta pod dôkladnou kontrolou nielen prostredníctvom edukácie, spotreby a korupcie. Zároveň dal do ich domovov namontovat' kamery a záznamy z nich sledoval vo svojej kancelárii na vel'kom premietacom plátne. $Z$ toho istého plátna si užíval aj prehliadky zbraní hromadného ničenia. Militaristickú vášeň pripísal Konwitschny do zbierky diktátorových hriechov, aby tak prezentoval d’alší zo svojich principiálnych občianskych postojov - odpor voči násiliu a zbrojeniu. Opät nešlo o ojedinelú javiskovú demonštráciu jeho presvedčenia, rovnaký postoj deklaroval napr. v inscenácii Halévyho grand opéry Židovka (SND, 2017, koprodukcia s Vlaamse Opera a Nationaltheater Mannheim). Dielo, ktoré prináša - dnes vyhrotene aktuálnu - tému náboženskej a kultúrnej intolerancie, interpretoval Konwitschny ako výstražný apel adresovaný modernej spoločnosti. Pritom neodsúdil samotné náboženstvá, ale zločiny páchané v ich mene, ked' vo svojej koncepcii nezvýhodnil žiadnu zo zúčastnených strán konfliktu. Ludskú neznášanlivost’ pranieroval bez konfesionálneho vymedzenia, vzájomne od seba odlišujúc protagonistov opery len farbou rúk: židia na nich nosili žlté a krestania modré rukavice. Radikálny protest proti kapitalizmu, obohacujúcemu sa na zbrojení, koncentroval režisér do finále tretieho dejstva. Po tom, čo Rachel s výbušninou pod kabátom vydesila krest’anov hrozbou samovražedného atentátu, sa všetci sólisti 
i zboristi postavili za továrenský pás. S gradujúcim hudobným tokom sa v odludštenej strojovej choreografii rozbehla výroba bombových opaskov. Tento výjav mal v štruktúre inscenácie centrálnu pozíciu nielen pre svoju vizuálnu sugestivitu, ale aj ako demonštrácia pacifistického zmýšlania režiséra: „Opera Židovka nás poučuje o tom, že musíme prestat' s týmto symetricky sa stupňujúcim násilím, vediet’ správne komunikovat’ a hl'adat' viac lásky. Aby zbrane vybuchli, musia sa niekde vyrobit'. Nemecko je na prvých priečkach vo vývoze zbraní. A aj Anglicko v 2. svetovej vojne velmi pekne zarobilo na zbraniach pre Nemcov. O tom je kapitalizmus. Ked' ide o profit, všetky humánne myšlienky sa zmetú zo stola. Výroba zbraní je ten najlukratívnejší obchod, preto sme v inscenácii vytvorili aj scénu s hromadnou výrobou zbraní. “21

Kým v Židovke predostrel režisér svoje pacifistické presvedčenie vážnym tónom, v inscenácii Verdiho Attilu (Theater an der Wien, 2013) zvolil karikujúcu výrazovú polohu. Centrálnym konfliktom skladatel'ovho raného diela, ktoré sa odohráva na území Talianska v 5. storočí nášho letopočtu, je stret západnej krest’anskej kultúry a barbarských Hunov vedených králom Attilom. Na jeho pozadí sa odvíja príbeh odbojnej Odabelly, ktorá sa v túžbe pomstit’ otcovu smrt’ votrie do Attilovej priazne, a d’alších dvoch potenciálnych vrahov barbarského uzurpátora - politicky ambiciózneho rímskeho generála Ezia a Odabellinho snúbenca Foresta. Konwitschny rozdelil dej do troch častí. Štyri obrazy tvoriace prológ a prvé dejstvo nazval „Detsky hraví", druhé dejstvo „Infantilne dospelí“, záverečné tretie dejstvo „Stále nepoučitel'ní". Hrdinov poháňaných túžbou po moci, kariére, uznaní a pomste pripodobnil v prvej časti inscenácie k chlapcom v tričkách, šortkách a „barbarských“ kožušinách, ktorí sa s bojovo pomal’ovanými tvárami naháňali na detskom ihrisku a podpichovali sa vareškami, metličkami, valčekmi, panvicami či kefami na čistenie toaliet. Ich vodca Attila stál na drevenom vozíku vyzbrojený bičíkom, ktorý si vyrobil z varechy a motúza, jeho „armáda“ ho povzbudzovala búchaním na panvice. V druhej časti prešli komické detské bitky do krutého dospelého levelu: varešky a bičíky vystriedali revolvery, naháňačka medzi chlapcami a dievčatami sa transformovala na vražednú ruskú ruletu. Posledný zápas medzi Hunmi a Rimanmi sa odohral v domove pre seniorov, na vozíkoch a rolátoroch: protagonisti opery ani v štádiu fyzickej bezmocnosti a blížiacej sa smrti neprestali viest’ nezmyselné, nikam nevedúce boje.

V modernej lavicovej ideológii ide pacifizmus ruka v ruke s ekokritikou. Ani Petrovi Konwitschnému nie je táto oblast' l’ahostajná, hoci sa jej nevenuje natol'ko často (a ani natol'ko úspešne) ako iným témam. Najzretel’nejšie ju pertraktoval v inscenácii Cherubiniho opery Medea (Staatsoper Stuttgart, 2017). Počas orchestrálnej predohry sa na spustenú oponu premietali pôsobivé zábery morských vín, ale túto audiovizuálnu idylu opticky narúšali pohodené plastové obaly na okraji vytŕčajúceho móla. Tvorcovia sa pri riešení scény inšpirovali fotografiami oceánológov, zachytávajúcimi obrovské polia plastových odpadkov - dôsledku bezohl'adnej l’udskej spotreby a drancovania prírody. Na javisku sa za vykachličkovanými kuchynskými stenami črtalo smetisko. Postupne prenikalo do interiéru vo forme hromadiacich sa obalov z nespočetných svadobných darov pre Iasona a Kreusu, až sa v plnej ošklivosti od-

${ }^{21}$ KONWITSCHNY, P. - VONGREJ, L'. Príbeh Židovky nás učí, že musíme prestat' s násilím a hl’adat’ viac lásky [Interview]. In Operaslovakia.sk, 7. 4. 2017. [online]. [cit. 10. 4. 2020]. Dostupné na internete: https:// operaslovakia.sk/peter-konwitschny-pribeh-zidovky-nas-uci-ze-musime-prestat-s-nasilim-a-hladat-viac-lasky/. 
krylo v poslednom dejstve, ked’ bola stena bytu odstránená a neporiadok interiéru splynul so smetiskom v exteriéri.

\section{Zodpovednost’ spoločnosti za tragédiu jednotlivca}

V stuttgartskej Medei pertraktoval režisér popri ekokritike aj d’alší z bodov svojej divadelno-politickej misie, ktorý javiskovou tvorbou kontinuálne reflektuje: presvedčenie, že za neštastie jednotlivca, vrátane ním spáchaných zločinov, je zodpovedná (či aspoň spoluzodpovedná) spoločnosṫ. To, že Medea v závere opery zavraždí svojich a Iasonových synov, nehovorí podla neho o tom, či je hrdinka dobrá alebo zlá, „ale popisuje spoločenský kontext, ktorý k tomuto neštastiu viedol. Čo zo záveru vyplýva, je to, že sa niečo musí zmenit. “22 Ak by totiž Medea deti nezabila sama, boli by sa stali obetłami Korint’anov, rovnako ako všetci cudzinci v Konwitschného inscenácii. Teda nielen Medea, ako to káže libreto Cherubiniho opery, ale aj jej slúžka Neris a exmanžel Iason. „Je to dôsledok nepriatel'skej nálady, ktorá tu tak či tak panuje, ked’že Medeu ako barbarku a cudzinku všetci nenávideli." ${ }^{23}$

Pretavenie tézy o zodpovednosti spoločnosti za osud jednotlivca nachádzame v mnohých Konwitschného javiskových prácach. Napríklad v inscenáciách oboch operných opusov Albana Berga, už spomenutého Wozzecka a tiež Lulu (Staatsoper Hamburg, 2003), ktoré patrili k plodom Konwitschného mimoriadne úspešnej spolupráce s mentálne spriazneným hudobným riaditelom Hamburskej štátnej opery, dirigentom Ingom Metzmacherom. Uznávaný odborník na Bergovo dielo, nemecký muzikológ Peter Petersen, nazval Konwitschného hamburské inscenácie diptychom, pričom ako ich spojivo vyzdvihol práve moment spoločenskej zodpovednosti za l'udské tragédie: „Tak vražda Marie ako aj vražda Lulu - obe mimochodom inscenované ako surreálne udalosti - sú predstavené ako kolektívny čin. Namiesto jediného páchatel'a je v oboch prípadoch navine jedna spoločenská trieda. ${ }^{24}$

Vo Wozzeckovi sa štylizovane aranžovaný akt Mariinej vraždy odohral tak, že si muži a ženy, stojaci v radoch oproti sebe ako dva nepriatel'ské tábory, vzájomne vymenili pozície choreograficky uhladeným prechodom cez javisko. Ked’ sa rozostúpili, uprostred javiska ostala ležat' Marie. Dav sa k nej rozbehol a zahrabal ju pod mohylu z rozsypaných bankoviek, Wozzeck, hladajúci imaginárny nôž medzi bankovkami, sa sám pochoval vedla nej. Slovami režiséra: „Hlavný rozpor v tomto diele nie je medzi Wozzeckom a Hajtmanom alebo medzi Wozzeckom a Doktorom, ale medzi l’ud’mi a neludsky organizovanou spoločnost’ou.“"25

V partitúre Lulu urobili režisér s dirigentom výrazné hudobno-dramaturgické úpravy. Najradikálnejšou bolo presunutie vraždy titulnej hrdinky z konca tretieho dejstva do nimi vytvoreného prológu, ktorý sa odohrával pred prvým dejstvom na

${ }^{22}$ KONWITSCHNY, P. - DANHAUSER, J. Medea im 21. Jahrhunderts [Interview]. In Luigi Cherubini: Medea [Bulletin k inscenácii]. Stuttgart : Staatsoper Stuttgart, 2017, s. 6.

${ }^{23}$ Tamže, s. 12.

${ }^{24}$ PETERSEN, P. Lulu geht. Anmerkungen zu Peter Konwitschnys zweitem Berg-Projekt (Hamburg 2003). In Archiv für Musikwissenschaft, 2015, roč. 72, č. 3, s. 237.

${ }^{25}$ KONWITSCHNY, P. - HINTZE, W. Selbst das Geld geht in Verwesung über Wozzeck von Alban Berg [rozhovor]. In Alban Berg: Wozzeck [Bulletin k inscenácii]. Cit podla WELKER, A. (ed.). Peter Konwitschny. „Mensch, Mensch, Mensch!" Oper als Zentrum der Gegenwart, s. 309. 


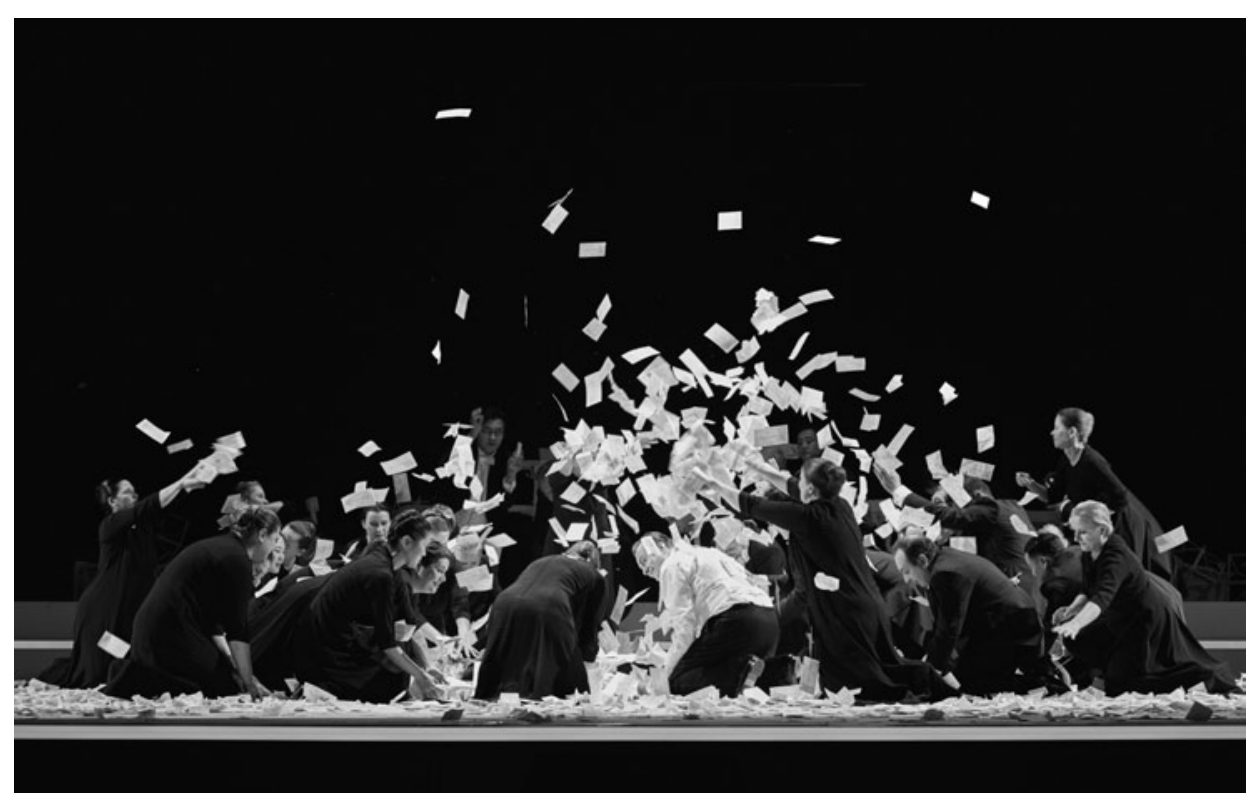

Alban Berg: Wozzeck. Staatsoper Hamburg, premiéra 27. 9. 1998, premiéra obnoveného naštudovania 14. 9. 2016. Réžia Peter Konwitschny. Foto Brinkhoff/Mögenburg.

hudbu Adagia z Lulu-Suite. ${ }^{26}$ Výtvarné riešenie scény odkazovalo na hamburskú zábavnú štvrt' Reeperbahn, ktorej súčastou sú popri divadlách, varieté, kluboch či baroch aj erotické domy. V oknách vel'kej kovovej konštrukcie pripomínajúcej klietku alebo väzenie sa predvádzali ženy vábiace zákazníkov, ktorých spomaleným pohybom privážal a odvážal pohyblivý pás, a nad javiskom sa vynímal vel'ký transparent s nápisom: „O čo radšej by som bola kurvou než na slávu a štastie najbohatším mužom." Muži vo frakoch - predstavitelia privilegovanej spoločnosti - zatiahli oponu a pred ňou si štylizovane posúvali z náručia do náručia míkvu, rezignovanú Lulu. Napokon ju brutálne strhli so sebou za oponu, kde sa odohral násilný skutok. V tomto výjave, ako poznamenáva Petersen, tvorcovia na spôsob analytickej drámy predznačili dej, avšak surrealisticky odcudzene, takže nemohol byt’ vnímaný ako skutočné dianie. Ked’že sa v Hamburgu, podobne ako na svetovej premiére v Zürichu (1937), inscenoval fragment bez tretieho dejstva, Lulu neskončila ako biedna prostitútka rukou Jacka Rozparovača. V závere druhého dejstva ju Konwitschny nechal, Petersenovými slovami, „opustit’ svet sexom posadnutých mužov a žien. Ostal ale - predovšetkým v hudbe vyjadrený - smútok za mnohými zmarenými pokusmi nájsț lásku. “27

${ }^{26}$ Toto riešenie bolo vlastne inverziou postupu, ktorý použili inscenátori pri svetovej premiére Lulu v Opernhaus Zürich (1937). Ked’že Berg umrel skôr, než operu dokončil (chýbalo zinštrumentovat’ záverečné tretie dejstvo) a žiadny z jeho oslovených kolegov neprijal ponuku vdovy Heleny Bergovej dielo finalizovat', opus bol uvedený ako fragment - po prvom a druhom dejstve nasledovala pantomíma na hudbu Lulu-Suite. Dielo dokončil až rakúsky skladatel' Friedrich Cerha, jeho verzia mala premiéru v roku 1979 v parížskom Palais Garnier.

${ }^{27}$ PETERSEN, P. Lulu geht. Anmerkungen zu Peter Konwitschnys zweitem Berg-Projekt (Hamburg 2003), s. 237. 


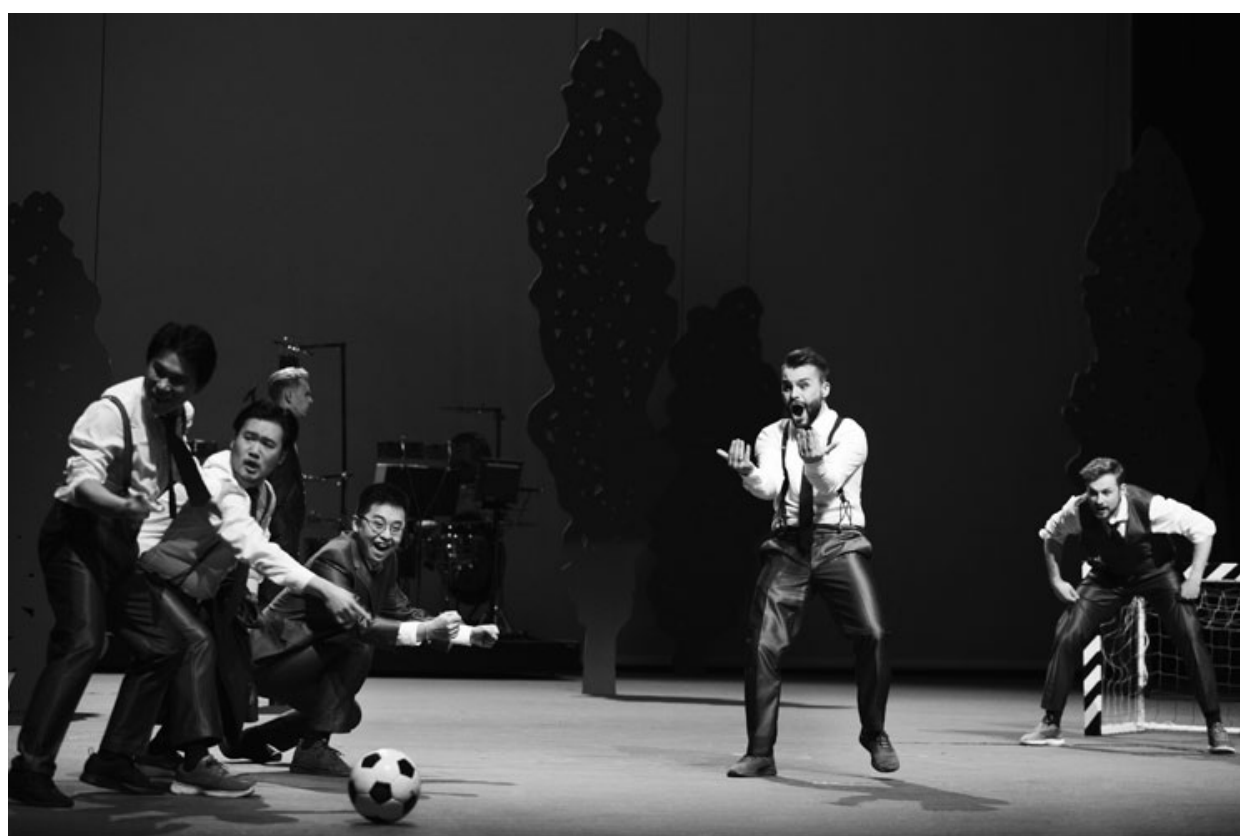

Bernd Alois Zimmermann: Die Soldaten. Staatstheater Nürnberg, premiéra 17. 3. 2018. Réžia Peter Konwitschny. Foto @ Ludwig Olah / Staatstheater Nürnberg.

Zmienené pokusy Lulu o nájdenie lásky boli v Konwitschného inscenácii vopred odsúdené na neúspech. Patriarchálna spoločnost', ktorej skazenost’ režisér aj v tejto inscenácii tvrdo pranieroval, sa prostredníctvom svojich predstavitelov Schigolcha a Schöna neštítila hrubo poznačit' osobnost' Lulu hned' v úvode jej životnej púte. Režisér to bez okolkov odhalil v prológu opery, v ktorom Krotitel' láka návštevníkov do cirkusu na zvieracie atrakcie. Jednou z nich je Lulu-had ${ }^{28}$, u Konwitschného zhmotnená do malého dievčatka v modrej sukni a cudnej bielej blúzke. Petersen vo svojej analytickej štúdii o tomto výjave napísal: „Každý pochopí, o čom sa v tejto srdce zasahujúcej scéne vypovedá: Diet’a bolo zneužité a deti budú vždy znova zneužívané. Podla môjho vedomia bol Konwitschny prvý, kto v librete a partitúre Lulu odhalil motív zneužívania detí a aj ho inscenačne zrealizoval.“29

Motív dietała zvedeného na zlú cestu rozvinul režisér do groteskne hyperbolizovaného scénického tvaru, v ktorom sa Lulu stala nástrojom na ukojenie potrieb mužov prechádzajúcich jej životom. Z jemného dievčatka z prológu sa v prvom obraze prvého dejstva transformovala do roztopašnej „lolitky“ s dvomi blond’avými vrkočmi, oblečenej v krátkych červených šatách s bielym golierikom, bielych podkolienkach a červených topánkach. Ked’ z nej infarkt manžela, ktorý ju pristihol pri sexe s Maliarom (ani tu nešlo z jej strany o dobrovolný akt), urobil vdovu, študentskú uniformu vymenila za elegantnú čiernu róbu s klobúkom. Pripomienkou jej dievčenské-

${ }^{28}$ Krotitel' o hadovi hovorí ako o sladkom a divom zvierati, prapôvodnej žene.

${ }^{29}$ PETERSEN, P. Lulu geht. Anmerkungen zu Peter Konwitschnys zweitem Berg-Projekt (Hamburg 2003, s. 229. 


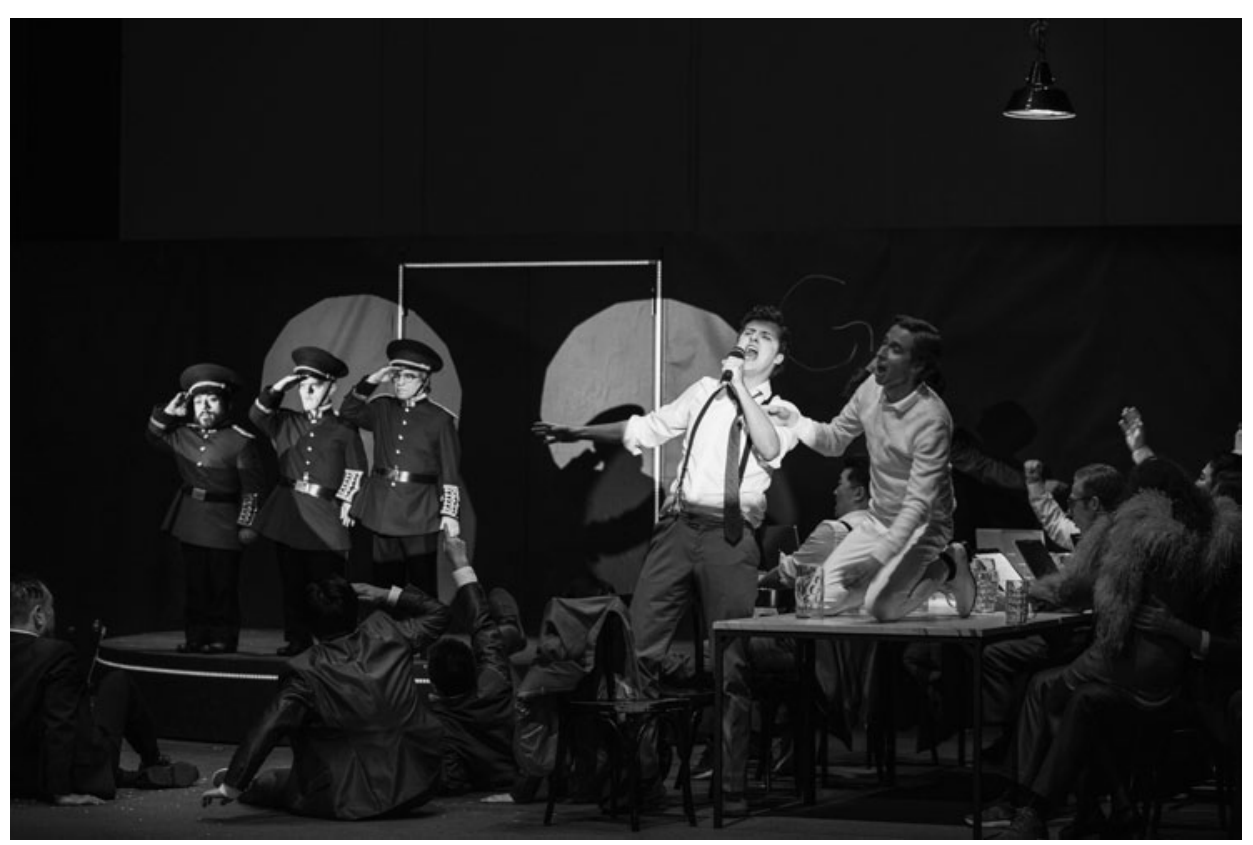

Bernd Alois Zimmermann: Die Soldaten. Staatstheater Nürnberg, premiéra 17. 3. 2018. Réžia Peter Konwitschny. Foto @ Ludwig Olah / Staatstheater Nürnberg.

ho ,ja“ ostala vel'ká nafukovacia bábika, na ktorej sa muži ukájali. „Namiesto obrazu Lulu, ktorý si zachováva svoju krásu napriek jej pádu, nám Konwitschny znepokojivo dáva bábiku v životnej vel'kosti, ktorá, ako portrét Doriana Graya, sa postupne mení na odpornú ikonu degradácie ${ }^{\star 30}$ komentoval britský operný kritik Tim Ashley.

Individuálna tragédia jednotlivca ako dôsledok všeobecného, spoločensky podmieneného rozkladu morálnych hodnôt sa stala nosným motívom aj v Konwitschného inscenácii opery Bernda Aloisa Zimmermanna Die Soldaten (Vojaci, Staatstheater Nürnberg, 2018). „Všetci v tomto opuse sú obet’ami. Mladé dievčatá, ktoré sú celkom vedome vychovávané $\mathrm{k}$ hlúposti - aby sa nechali zneužívat'. Ale rovnako aj muži, ktorí sú manipulovaní k tomu, aby boli ochotní umriet', za čo dostanú pár darčekov - napríklad tamtie dievčatá, alebo sedemdesiat panien v nebi, prípadne nejaké vyznamenanie. Nie sú také/takí, pretože by boli naozaj hlúpe/hlúpi, ale preto, lebo ich $\mathrm{k}$ tomu vedie výchovný systém, školy a univerzity, cirkev... ${ }^{\text {"31 }}$ argumentoval režisér $\mathrm{v}$ bulletine.

Konwitschného vojaci nebývali v kasárňach, ale boli jednoliatou masou bankových úradníkov a burzových maklérov, z ktorých uniformnost’ sivých oblekov zotrela akúkol'vek individualitu. Títo muži „sú pripravení konat’ deštruktívne, ak k tomu dostanú príkaz zhora. Tak ako napríklad v kapitalistických spoločnostiach, napríklad

${ }^{30}$ ASHLEY, T. Going out with a bang. In The Guardian, 21. 11. 2003. [online]. [cit. 1. 2. 2020]. Dostupné na internete: https://www.theguardian.com/music/2003/nov/21/classicalmusicandopera.germany. 2018.

${ }^{31}$ In Bernd Alois Zimmermann: Die Soldaten [Bulletin k inscenácii]. Nürnberg : Staatstheater Nürnberg, 
v bankovníctve ${ }^{32}$ ". Svoje egá si presadzovali na futbalovom ihrisku, prípadne v kaviarni pani Roux, kde prácu na laptopoch prekladali pitím piva a vystatovačnými šarvátkami. Otec Marie Wesenerovej bol vypočítavý špekulant, vidiaci v cynickom dôstojníkovi Desportovi, ktorý kurizoval jeho dcére, príležitost’ na zlepšenie vlastného sociálneho statusu. Skutočnost', že Marie sa už predtým zasnúbila s idealistickým mladíkom Stolziusom, nehrala v tomto obchode nijakú rolu. Stolziusova túžba zabit’ Mariinho zvodcu, ktorého považoval za príčinu svojho neštastia, sa vystupňovala, ked' sa nechal najat' ako sluha Desportovho priatela Maryho. Práve ponižovanie zo strany maskulínnych dôstojníkov (Mary ho navliekol do rovnakého lokajského obleku, aký nosili traja trpaslíci zabávajúci dôstojníkov v kaviarni; Desportes počas večere, ktorú im servíroval Stolzius, cynicky rozprával Marymu o tom, ako podhodil Marie svojim vojakom) vyvrcholilo zavraždením oboch trýznitel’ov a následne Stolziusovou samovraždou. Rovnako smutný bol koniec Marie. Zvnútra motivovaná vlastnou túžbou po pohodlnom, luxusnom živote a zvonku manipulovaná ziskuchtivým otcom i bezohl'adným predátorom Desportom, prežila v Konwitschného inscenácii rýchly vzostup zo sladkého meštiackeho dievčatka na výslnie luxusnej, obletovanej „call-girl“ a potom rovnako rýchly pád na dno, kde ju ako vyhladnutú prostitútku žobrajúcu medzi divákmi o kúsok chleba nepoznal ani vlastný otec. ${ }^{33}$

Osudy Wozzecka, Stolziusa aj oboch Marie (Bergovej i Zimmermannovej) vyvrcholili - v režisérových koncepciách rovnako ako v operných partitúrach - tragicky. $\mathrm{O}$ čosi viac štastia mala Lulu. Vzhl'adom na inscenovanie fragmentu bez Cerhom dokončeného tretieho dejstva, kde by ju zavraždil Jack Rozparovač, ju režisér nechal opustit mužský svet, pre ktorý predstavovala len nástroj na ukojenie sexuálnych chút’ok - avšak samu, bez lásky. Najlepšie dopadla titulná hrdinka Straussovej opery Salome, ktorej život ukončuje v librete otčim Herodes rozkazom: "Zabite tú ženu!" U Konwitschného sa jej v závere podarilo vyslobodit’ z Herodesovho dvora, ktorý vo svojej recenzii sugestívne popísala kritička Julia Spinola: „Svet je miestom klaustrofóbie. Stvorcová šachta bez dverí a okien, ktorej jedinými otvormi je niekol'ko zašpinených vetracích trubíc s trčiacimi drôtmi. Uzavretá spoločnost', ktorá je tu uväznená, dosiahla smrtelné štádium šialeného kapitalistického drancovania a vykoristovania. Posledné nálepky civilizácie opadli, príroda bola strávená a vyplienená a to málo, čo z nej predsa len ostalo - zvyšok duševnej a telesnej vitality - je d’alej šikanované, mučené a zosmiešňované a požierané. “34 Pri zobrazení odpudivej society využil režisér výrazový aparát hororu i drsnej grotesky. Jej členovia sa neštítili nijakých odporností: Herodias smilnila pod stolom priamo pri manželových nohách, Narrabotha prítomní muži znásilnili, zavraždili a jeho mŕtvolu zabalili do koberca. Salome sa z tohto pekla vymanila s Jochanaanom, ktorého hlavu si mala od otčima vypýtat' ako odmenu za svoj tanec. S poslednými taktmi opery spoločne zahrnuli oponu a z proscénia utiekli cez zákulisie preč.

\footnotetext{
${ }^{32}$ Tamže.

${ }^{33}$ Viac o tejto mizanscéne, v ktorej P. Konwitschny dospel na bezprostrednú hranicu medzi iluzívnym a imerzným divadlom, aj o režisérovej práci s publikom pozri MOJŽIŠOVÁ, M. Umelecké taženie režiséra Petra Konwitschného proti „mŕtvej opere“. In Slovenské divadlo, 2019, roč. 67, č. 4, s. 335 - 352.

${ }^{34}$ SPINOLA, Julia. Salome darf nicht sterben. In Frankfurter Allgemeine Zeitung, 12. 11. 2019. [online]. [cit. 15. 3. 2020]. Dostupné na internete: https://www.faz.net/aktuell/feuilleton/buehne-und-konzert/salome-inamsterdam-salome-darf-nicht-sterben-1885286.html.
} 
Utopický únik z bezútešnej reality ako cesta k osobnej slobode je Konwitschného opakovane overovaným receptom na to, ako sa sa vymanit’ z pút sebeckej, krutej kapitalistickej spoločnosti. V kontexte jeho lavicového, nekompromisne antipatriarchálneho pohl'adu na svet neprekvapuje, že sú to v drvivej väčšine prípadov ženské hrdinky, kto dokáže nájst’ odvahu k radikálnemu činu, prípadne k nemu zmotivovat aj svojho mužského partnera. Lulu a Salome neboli jedinými v tomto rade, podobne „utopicky“ sa v Konwitschného inscenáciách skončil javiskový osud Verdiho Aidy, Wagnerovej Isoldy i Brünhildy či Janáčkovej Emilie Marty. Ako konštatoval teatrológ Claus Spahn: „Pri Petrovi Konwitschnom je to vždy tak: Ženy sú vykupitel'ky, len ony ešte majú zmysel pre utópiu. “ ${ }^{\text {35 }}$

\section{PETER KONWITSCHNY AND HIS OPERA-THEATRICAL CRITICISM OF THE MORALITY OF CAPITALISM}

\section{Michaela MOJŽIŠOVÁ}

In principle, the theatrical work of the German opera director Peter Konwitschny is determined by his left-wing political beliefs. The study focuses on some of the phenomena of Western (capitalist) society which are constantly subject to criticism in his productions. In addition to rejecting the patriarchal principles of the organisation of society, it is primarily the dependence of modern civilisation on materiality, the consumerist way of life, and the disruption of moral values which ensues from it.

Príspevok je súčastou riešenia projektu APVV č. 15-0764 Slovenské divadlo a súčasná európska divadelná kultúra - kontinuita a diskontinuita.

\section{LITERATÚRA}

ASHLEY, Tim. Going out with a bang. In The Guardian, 21. 11. 2003. [online]. [cit. 1. 2. 2020]. Dostupné na internete: https://www.theguardian.com/music/2003/nov/21/classicalmusicandopera.germany. ISSN 1756-3224.

BAYER, Robert. Ako (ne)zabit’ draka. In Hudobný život, 2020, roč. 52, č. 1 - 2, s. 43. ISSN 13354140.

DIPPEL, Roland H. Im Kampf gegen die totalitäre Macht. In Oper \& Tanz, 1/2020. [online]. [cit. 15. 3. 2020]. Dostupné na internete: https://www.operundtanz.de/archiv/2020/01/berichte_02_lanzelot.shtml ISSN 0474-2478.

KONWITSCHNY, Peter - BARTZ, Bettina. Die Reeperbahn spielt mit. In Alban Berg: Lulu [Bulletin k inscenácii]. Cit. podla WELKER, Andrea (ed.). Peter Konwitschny. „Mensch, Mensch, Mensch!" Oper als Zentrum der Gegenwart, s. 356 - 359. ISBN 978-3-99028-436-0.

KONWITSCHNY, Peter - BARTZ, Bettina. Was unter der Oberfläche brodelt. In Piotr Iljič Čajkovskij: Pique dame [Bulletin k inscenácii]. Graz : Oper Graz, 2011, s. 4-6.

KONWITSCHNY, Peter - BARTZ, Bettina - WEGNER, Hans-Georg. Lanzelot in Weimar. In Paul Dessau: Lanzelot [Bulletin k inscenácii], s. 9 - 17.

${ }^{35}$ SPAHN, C. Der Kopf bleibt dran. In WELKER, A. (ed.). Peter Konwitschny. „Mensch, Mensch, Mensch!" Oper als Zentrum der Gegenwart, s. 452. 
KONWITSCHNY, Peter - DANHAUSER, Johanna. Medea im 21. Jahrhunderts. In Luigi Cherubini: Medea [Bulletin k inscenácii], s. $4-13$.

KONWITSCHNY, Peter - DEMATTIA, Oswald. Ich möchte eine therapeutische Wirkung [Interview]. In Der Standard, 14. 11. 2003. [online]. [cit. 29. 1. 2020]. Dostupné na internete: https://www.derstandard.at/story/1476773/ich-moechte-eine-therapeutische-wirkung. ISSN 1563-5430.

KONWITSCHNY, Peter - HINTZE, Werner. Selbst das Geld geht in Verwesung über Wozzeck von Alban Berg. In Alban Berg: Wozzeck [Bulletin k inscenácii]. Cit. podla WELKER, Andrea (ed.). Peter Konwitschny. "Mensch, Mensch, Mensch!“ Oper als Zentrum der Gegenwart, s. 306 309. ISBN 978-3-99028-436-0.

KONWITSCHNY, Peter - SPAHN, Carl. Die machen sich überhaupt keinen Kopf [Interview]. In Die Zeit, 2001, roč. 55, č. 19, s. 49 - 50. ISSN 0044-2070.

KONWITSCHNY, Peter - ULIČIANSKA, Zuzana. Opery nám ukazujú, ako so sebou nezaobchádzat' [Interview]. In Sme, 2007, roč. 15, č. 280, s. 23, 6. 12. 2007. ISSN 1335-440X.

KONWITSCHNY, Peter - VONGREJ, L'udovít. Príbeh Židovky nás učí, že musíme prestat’ s násilím a hl'adat viac lásky [Interview]. In Operaslovakia.sk, 7. 4. 2017. [online]. [cit. 10. 3. 2020]. Dostupné na internete: https://operaslovakia.sk/peter-konwitschny-pribeh-zidovky-nas-uci-ze-musime-prestat-s-nasilim-a-hladat-viac-lasky/. ISSN 2453-6490.

MOJŽIŠOVÁ, Michaela. The Picture of a Family Crisis and the Criticism of Patriarchy in the Works of Director Peter Konwitschny. In KNOPOVÁ, E. (ed.). Theatre as a Value-based Discourse: Slovak Theatre and Contemporary European Theatre Culture. Bratislava : Veda, 2018, s. 152 - 166. ISBN 978-80-224-1705-1.

MOJŽIŠOVÁ, Michaela. Umelecké taženie režiséra Petra Konwitschného proti „mŕtvej opere“. In Slovenské divadlo, 2019, roč. 67, č. 4, s. 335 - 352. ISSN 0037-699X.

PETERSEN, Peter. Lulu geht. Anmerkungen zu Peter Konwitschnys zweitem Berg-Projekt (Hamburg 2003). In Archiv für Musikwissenschaft, 2015, roč. 72, č. 3, s. 213 - 237.

SPAHN, C. Der Kopf bleibt dran. In WELKER, Andrea (ed.). Peter Konwitschny. „Mensch, Mensch, Mensch!“ Oper als Zentrum der Gegenwart, s. 452 - 453. ISBN 978-3-99028-436-0.

SPINOLA, Julia. Salome darf nicht sterben. In Frankfurter Allgemeine Zeitung, 12. 11. 20019. [online]. [cit. 15. 3. 2020]. Dostupné na internete: https://www.faz.net/aktuell/feuilleton/ buehne-und-konzert/salome-in-amsterdam-salome-darf-nicht-sterben-1885286.html. ISSN 0174-4909.

WELKER, Andrea (ed.). Peter Konwitschny. „Mensch, Mensch, Mensch!“ Oper als Zentrum der Gegenwart. Weitra : Verlag Bibliothek der Provinz, 2015. ISBN 978-3-99028-436-0. 525 s. ISBN 978-3-99028-436-0.

Michaela Mojžišová

Ústav divadelnej a filmovej vedy CVU SAV

Dúbravská cesta 9

84104 Bratislava

e-mail: michaela.mojzisova@savba.sk 